\title{
Kesan Penuaan ke atas Kehubungan Berkesan Otak semasa Pemprosesan Persepsi Pertuturan daripada Perspektif Pemodelan Sebab dan Akibat Dinamik: Satu Kajian fMRI
}

(Effects of Aging on Effective Brain Connectivity during Speech Perception Processing from Dynamic Causal Modeling Perspective: An fMRI Study)

\author{
HANANi ABDUl MANAN*, AHMAD NAZlim YUSOFF \& Siti ZAMraTOL-MAi SARAH MUKARI
}

\section{ABSTRAK}

Proses penuaan seringkali dikaitkan dengan kemerosotan pada sistem kognitif. Kemerosotan kognitif bermula seawal usia dua puluhan dan berterusan secara linear. Selain itu, kemerosotan kognitif juga menjadi lebih nyata dengan kehadiran hingar latar. Walau bagaimanapun, kesan penuaan ke atas mekanisme pemprosesan persepsi pertuturan menggunakan tugasan mengulang secara terus (FRT) dalam senyap dan hingar belum difahami dengan jelas. Dalam kajian ini, pengimejan resonans magnet kefungsian (fMRI) digunakan untuk membandingkan kesan penuaan ke atas kehubungan efektif otak yang terhasil daripada tugasan FRT ke atas subjek normal dengan empat kumpulan umur yang berlainan iaitu 20 - 29 tahun $(\mathrm{n}=15), 30$ - 39 tahun $(\mathrm{n}=15), 40$ - 49 tahun $(\mathrm{n}=10)$ dan 50 - 65 tahun $(\mathrm{n}=14)$. Satu siri lima perkataan yang diselang-seli dalam keadaan hingar dengan senyap diberikan secara auditori. Pemetaan statistik berparameter (SPM8) dan pemodelan dinamik penyebab (DCM10) digunakan untuk menentukan kehubungan efektif otak. Kawasan yang terlibat dalam pembinaan model kehubungan efektif otak adalah STG, HG dan PCG. Model optimum yang dipilih dalam kajian ini adalah model yang menunjukkan keseimbangan antara ketepatan dan kesukaran. Keputusan fMRI kehubungan efektif menunjukkan bahawa komunikasi antara intrahemisfera tidak berubah dengan menggunakan tugasan FRT ini apabila seseorang semakin berusia, tetapi komunikasi antara interhemisfera menjadi semakin kompleks.

Kata kunci: DCM; fMRI; kehubungan efektif; pemprosesan auditori; penuaan

\section{ABSTRACT}

Aging process is often associated with a deterioration in cognitive system. The decline begins as early as in the twenties and continues linearly. Other than that, the decline also becomes more pronounced in the presence of background noise. However, the effects of aging on the mechanisms of speech perception processing using forward repeat task (FRT) in quiet and in noise have not yet clearly understood. In this study, functional magnetic resonance imaging (fMRI) was used to compare the effects of aging on effective connectivity resulting from FRT tasks on normal subjects with four different age groups which are 20 - 29 years $(\mathrm{n}=15), 30$ - 39 years $(\mathrm{n}=15), 40-49$ years $(\mathrm{n}=10)$ and $50-65$ years $(\mathrm{n}=14)$. A series of five words interspersed in noise and in quiet were given using auditory stimulus. Statistical parametric mapping (SPM8) and dynamic causal modeling (DCM10) was used to determine the effective connectivity. Three areas, STG, HG and PCG were selected to built effective connectivity models. The effective connectivity results using FRT task showed there is no significant changes in the intrahemispheric connectivity when a person gets older, however the interhemispheric communication becomes more complex.

Keywords: Ageing; auditory processing; DCM; effective connectivity; fMRI

\section{PENGENALAN}

Proses penuaan menyebabkan perubahan pada struktur dan fungsi otak. Sebahagian besar pengetahuan tentang kesan penuaan ke atas otak manusia adalah sumbangan daripada autopsi dan juga pengimejan neuro. Salah satunya ialah hasil kajian yang dilakukan oleh Habes et al. (2016) yang mendapati bahawa isi padu ventrikel otak membesar sebanyak $1526 \mathrm{~mm}^{3}$ dalam masa setahun yang bermula pada usia pertengahan dewasa (35 - 40 tahun) dan pada masa yang sama keadaan ini menyumbang kepada penurunan isi padu jirim-kelabu dan jirim-putih dalam otak manusia. Penurunan isi padu jirim-kelabu dan jirim-putih ini dikaitkan dengan kemerosotan pada sistem kognitif (Davis et al. 2012) dan digelar penuaan kognitif. Selain daripada kemerosotan dalam isi padu jirim-kelabu dan jirim-putih, proses penuaan kognitif juga dikaitkan dengan banyak kemerosotan lain termasuk atrofi pada sistem neuron, degenerasi sinaptik, pengaliran darah menjadi perlahan dan perubahan neurokimia dalam otak (Li et al. 2015; Manan et al. 2015). Dengan perubahan yang berlaku pada sistem otak ini, maka tidak hairanlah jika penuaan menyebabkan prestasi kognitif individu berusia merosot 
dalam pelbagai tugasan kognitif termasuklah pemprosesan persepsi pertuturan. Walau bagaimanapun, kesan penuaan ini dipercayai tidak berlaku secara seragam. Kesan penuaan ke atas kawasan otak tertentu adalah berbeza dengan kawasan otak yang lain dan kemerosotan ini juga berbeza daripada seorang individu kepada individu yang lain.

Selain daripada perubahan dan kemerosotan pada sistem kognitif seperti pemprosesan persepsi pertuturan, penuaan juga menyebabkan kebolehan untuk mendengar dalam hingar atau dalam persekitaran yang bising turut menjadi sukar (Alain et al. 2014; Molander \& Backman 1990). Ini diandaikan disebabkan oleh kemerosoton pada sistem pemprosesan penumpuan dan pemprosesan auditori (Babkoff \& Fostick 2017; Brooks et al. 2015). Dengan kehadiran hingar, keupayaan penumpuan yang lebih tinggi diperlukan dalam memberi tumpuan kepada stimulus utama atau dalam mendiskriminasi antara pertuturan dan hingar latar. Ini kerana individu berusia sangat terganggu oleh bunyi novel tidak relevan misalnya hingar berbanding individu muda. Proses mendiskriminasi hingar menjadi lebih kritikal dalam suasana hingar jenis pertuturan atau cocktail party noise, contohnya perbualan di pasar atau perbualan di restoran dengan banyak perbualan berlaku secara serentak (Soderlund et al. 2010; Sohn \& Lee 2000).

Dalam kajian ini, kesan penuaan terhadap pemprosesan persepsi pertuturan dikaji. Bagi melihat kesan penuaan ke atas pemprosesan persepsi pertuturan, kajian ini menggunakan tugasan mengulang secara terus (FRT) secara verbal (fonologi). FRT telah digunakan secara meluas untuk menilai fungsi pemprosesan kognitif, auditori dan persepsi pertuturan. Kajian ini adalah kajian keratan rentas yang dilakukan ke atas empat kumpulan subjek berusia antara 20 hingga 65 tahun. Kajian ini bertujuan untuk menentukan bilakah bermulanya perubahan sifat kehubungan otak. Kajian kesan penuaan ini adalah penting untuk dilakukan sebagai kesinambungan kepada kajian terdahulu yang hanya membincangkan kesan penuaan ke atas pengaktifan otak (Manan et al. 2015; 2014).

\section{BAHAN DAN KAEDAH}

\section{SUBJEK KAJIAN}

Kajian fMRI ini dijalankan ke atas lima puluh empat orang subjek lelaki Melayu dewasa sihat berumur antara 20 hingga 65 tahun dan dominan tangan kanan.
Subjek dibahagikan kepada empat kumpulan mengikut peringkat umur; 20 - 29 tahun (kumpulan 1), 30 - 39 tahun (kumpulan 2), 40 - 49 tahun (kumpulan 3) dan 50 - 65 tahun (kumpulan 4). Pengiraan sampel saiz adalah berdasarkan kepada analisis yang dilakukan oleh pengkaji sebelum ini (Desmond \& Chen 2002; Desmond \& Glover 2002). Subjek diwajibkan menjalani dan lulus ujian saringan seperti: ujian cangkat tangan yang menggunakan Edinburgh Handedness Inventory (Oldfield 1971), ujian mini mental (Anthony et al. 1982; Richardson \& Glass 2002) dan ujian saringan pendengaran (yang diadaptasi daripada Rochester Hearing \& Speech Center http://www. rhsc.org/ dan ujian saringan dalam bentuk audio http:// www.starkey.com) sebelum dibenarkan untuk menjalani pemeriksaan fMRI. Data demografi adalah seperti dalam Jadual 1 (Abdul Manan et al. 2015).

Terdapat beberapa kriteria inklusi dalam pemilihan subjek; subjek mestilah penutur asli Bahasa Melayu, ini kerana stimulus yang digunakan adalah dalam Bahasa Melayu dan bagi mengelak faktor luar yang mungkin menyumbang kepada keputusan kajian antaranya tidak memahami stimulus yang digunakan. Subjek juga mestilah sihat daripada segi mental dan fizikal serta tidak menggunakan sebarang ubat psikoaktif. Penjelasan penuh dan risiko kajian terlebih dahulu diberitahu kepada subjek. Subjek faham dan bersetuju untuk menyertai kajian ini dengan mengisi borang persetujuan. Kajian ini telah mendapat kelulusan dan mengikut protokol yang telah diluluskan oleh Jawatankuasa Etika Penyelidikan Universiti Kebangsaan Malaysia (No. Rujukan: UKM 1.5.3.5/244 / NN-075-2009).

\section{PEMEROLEHAN DATA IMBASAN fMRI}

Imbasan pengimejan resonans magnet kefungsian (fMRI) dijalankan di Jabatan Radiologi, Pusat Perubatan UKM dengan menggunakan sistem pengimejan resonans magnet (MRI) (model Siemens Avanto) 1.5 tesla yang dilengkapi dengan protokol pengimejan kefungsian. Gegelung frekuensi radio (RF) kepala dipakaikan kepada subjek untuk pemberian dan penerimaan isyarat kepala daripada otak. Imbasan kefungsian dijalankan menggunakan protokol pengimejan BOLD dengan jujukan denyut pengimejan gemaan satah (EPI) gema kecerunan medan (GKM) bagi memperolehi imej berwajaran T2*. Parameter pengimejan bagi jujukan denyut EPI-GKM adalah seperti berikut: masa ulangan $(\mathrm{TR})=2 \mathrm{~s}$, masa menggema $(\mathrm{TE})=50 \mathrm{~ms}$, bidang penglihatan $(\mathrm{FOV})=192 \times 192 \mathrm{~mm}$, sudut flip $(\alpha)=90^{\circ}$,

JADUAL 1. Data demografi empat kumpulan umur yang mengambil bahagian dalam kajian persepsi pertuturan dengan menggunakan tugasan FRT

\begin{tabular}{ccccc}
\hline Julat Umur & $20-29$ & $30-39$ & $40-49$ & $50-65$ \\
\hline$N$ & 15 & 15 & 10 & 14 \\
Umur (lingkungan) & $23-29$ & $30-37$ & $41-47$ & $55-65$ \\
Umur (purata \pm SD) & $27 \pm 2.18$ & $33 \pm 2.18$ & $45 \pm 2.28$ & $61 \pm 6.02$ \\
Bilangan tahun pendidikan (purata \pm SD) & $14.8 \pm 0.79$ & $15.4 \pm 1.5$ & $13.9 \pm 3.16$ & $13 \pm 2.46$ \\
\hline
\end{tabular}


saiz matriks $=128 \times 128$ dan ketebalan hirisan $=5 \mathrm{~mm}$ (jarak antara hirisan $=1.25 \mathrm{~mm}$ ). Imej struktur otak berwajaran T1 diperoleh menggunakan jujukan denyut pembinaan semula multi satah (MPR) dengan parameter berikut: $\mathrm{TR}=1240 \mathrm{~ms}, \mathrm{FOV}=250 \mathrm{~mm} \times 250 \mathrm{~mm}$, sudut flip $=90^{\circ}$, saiz matriks $=128 \times 128$ dan ketebalan hirisan $=1$ $\mathrm{mm}$. Keseluruh isi padu otak yang diimbas terdiri daripada 21 hirisan termasuk kawasan serebelum. Parameter yang digunakan dalam pemerolehan data fMRI ini adalah sama seperti dalam Manan et al. (2015).

\section{STIMULUS PERSEPSI PERTUTURAN(FRT)}

Stimulus persepsi pertuturan (FRT) yang digunakan dalam kajian ini adalah satu siri perkataan yang terdiri daripada lima perkataan yang bererti (kata-nama dan kata-kerja) yang dihasilkan dengan merakam suara lelaki dewasa Melayu, direkodkan menggunakan perisian Sony Voice Editor, disimpan dan disunting menggunakan perisian Adobe Audition 2.0. Contoh stimulus yang direkodkan adalah seperti 'merah, marah, buku, potong, ramah'. Aras keamatan stimulus adalah $55 \mathrm{~dB}$ (Manan et al. 2014).

\section{PARADIGMA DAN PROSEDUR}

Seperti yang ditunjukkan dalam Rajah 1(a), stimulus yang digunakan terdiri daripada lima perkataan yang terdiri daripada kata kerja (KK) dan kata nama (KN) yang telah dipilih secara rawak untuk membina stimulus yang diperdengarkan semasa tempoh uji kaji. Tempoh untuk satu perkataan adalah $0.6 \mathrm{~s}$ dan dipisahkan oleh jurang $0.5 \mathrm{~s}$. Jumlah keseluruhan masa untuk satu percubaan adalah 5 s. Sebanyak 30 perkataan (2 suku kata dan 3 suku kata) digunakan untuk menghasilkan stimulus dalam kajian ini. Rajah 1(b) menunjukkan kedudukan stimulus dalam kajian ini iaitu 40 set percubaan persepsi pertuturan dalam senyap (FRT-senyap) dan persepsi pertuturan dalam hingar (FRThingar) yang selang-selikan dengan tanpa stimulus (masa rehat). Bagi kesemua perkataan yang diperdengarkan, subjek diberi masa selama $5 \mathrm{~s}$ untuk mengulangi secara terus apa yang didengari. Masa keseluruhan untuk setiap percubaan adalah $16 \mathrm{~s}$. Turutan ini diulang sebanyak 40 kali dengan masa imbasan total adalah 21.3 min untuk setiap subjek. Paradigma dan prosedur adalah seperti dalam Manan et al. (2015; 2014; 2013). Kajian ini menggunakan paradigma pengimejan jarak (fMRI senyap) untuk mengelakkan imej kefungsian yang diperoleh diganggu oleh bunyi mesin pengimbas MRI (Hall et al. 1999).

\section{PROSEDUR FMRI DAN UJIAN TINGKAH LAKU}

Sebelum memasuki bilik pemeriksaan fMRI, arahan mengenai tugasan yang bakal dilakukan diterangkan secara terperinci kepada subjek dan subjek diarahkan untuk menumpukan perhatian sepanjang imbasan dilakukan. Semasa imbasan, subjek dibaringkan dalam kedudukan yang selesa dalam pengimbas MRI. Sepan cegah gerak diselitkan antara kepala subjek dan gegelung RF kepala untuk menghadkan pergerakan kepala. Stimulus diberikan

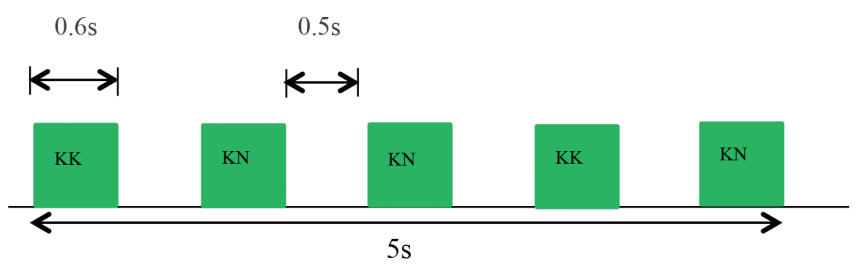

(a)

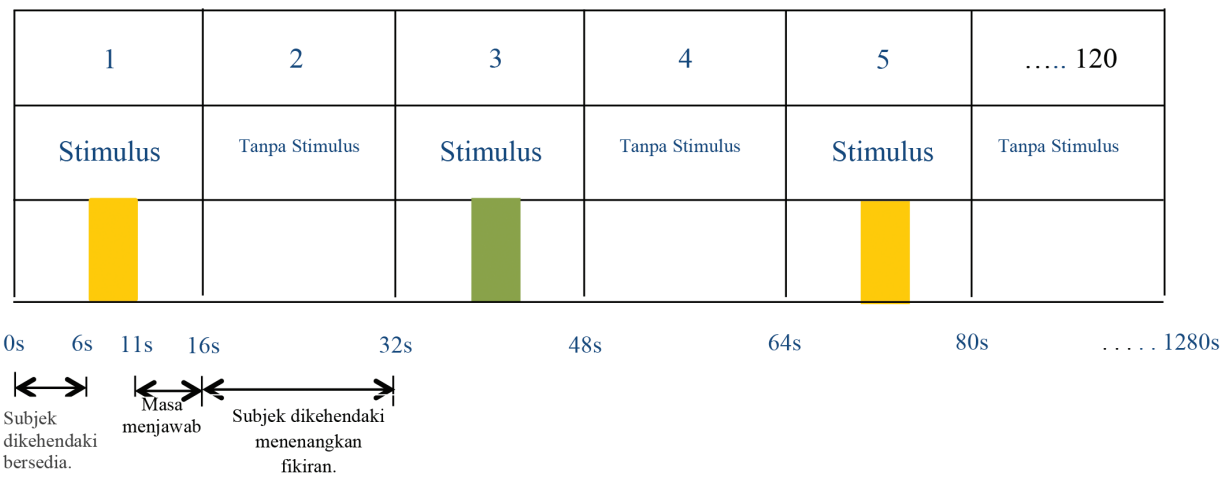

(b)

Stimulus tanpa hingar

Stimulus dengan hingar

RAJAH 1. Paradigma stimulus yang digunakan semasa uji kaji: KN adalah kata nama dan manakala KK adalah kata kerja 
secara auditori melalui fon telinga (Model Nordic fMRI Solution Audio System) yang disambungkan kepada pemain cakera. Semasa imbasan, skor (jawapan yang betul) bagi setiap subjek direkodkan secara manual oleh penyelidik di luar bilik pemeriksaan MRI (Manan et al. 2013a).

Bagi subjek kumpulan 4 (50 - 65 tahun), ujian mini mental turut dilakukan ke atas setiap subjek. Ujian mini mental ini dilakukan sebelum ujian fMRI dan ujian tingkah-laku diberikan. Ujian ini adalah ujian saringan bagi memastikan sistem kognitif subjek masih berada dalam keadaan yang baik. Subjek dengan skor ujian mini mental di bawah 28 tidak dipilih untuk menjadi subjek dalam kajian ini.

\section{ANALISIS KEHUBUNGAN EFEKTIF}

Data fMRI dianalisis dengan menggunakan pemetaan statistik berparameter versi 2008 atau SPM8 (Functional Imaging Laboratory, Department of Imaging Neuroscience, Institute of Neurology, University College London, UK; http:// www.fil.ion.ucl.ac.uk/spm) yang menggunakan MATLAB 7.4 - R2008a (Mathworks Inc. MA, Amerika Syarikat) sebagai pelantar. Dua isi padu imej yang pertama bagi setiap sesi imbasan kefungsian tidak digunakan dalam analisis data. Ini bertujuan untuk memastikan medan magnet telah mencapai fasa yang stabil (Manan et al. 2012).

Analisis kehubungan efektif adalah lanjutan kepada analisis pengkhususan kefungsian yang bertujuan untuk melihat saling hubungan atau interaksi antara satu kawasan otak dengan kawasan yang lain. Enam kawasan otak telah dipilih dalam kajian ini iaitu girus Heschle's (HG), girus temporal superior (STG) dan girus presentral (PCG) di keduadua belah hemisfera. Model interaksi antara kawasan otak dibina. Bagi tujuan ini analisis model dinamik penyebab (DCM) digunakan. DCM digunakan untuk membina model kehubungan neuron yang munasabah dan realistik yang menunjukkan interaksi kawasan korteks yang terlibat dalam sesuatu tugasan dengan parameter neurofisiologi. Parameter ini adalah berdasarkan kepada kesan BOLD, iaitu dengan melihat kawasan otak yang teraktif dan model DCM akan dibina berdasarkan kawasan otak ini. Semasa penetapan koordinat untuk mendapatkan voxsel yang dikehendaki (VOI), nilai jejari di sekeliling koordinat voxsel pilihan ditetapkan sebesar $4 \mathrm{~mm}$. Bagi kawasan otak yang sama, jarak antara VOI analisis kesan rawak (RFX) dengan setiap VOI individu mestilah tidak melebihi $6 \mathrm{~mm}$. Ini bertujuan untuk memastikan setiap voI berada pada kawasan otak yang sama. Manakala VOI antara satu kawasan dengan kawasan lain (kawasan otak yang berbeza) dalam individu yang sama jaraknya mestilah melebihi 16 mm, supaya tidak bertindih antara satu kawasan dengan kawasan yang lain. Model kehubungan efektif untuk setiap individu dibina dengan menggunakan VOI yang dipilih ini (Kiebel 2006; Penny 2004).

Model DCM dalam kajian ini dibina melalui tiga fasa. Model ini dibina berdasarkan kehubungan secara kebelakang, ke hadapan, sesiri dan selari. Fasa pertama adalah pembinaan model berkehubungan penuh bagi mendapatkan masukan input. Fasa ini adalah untuk menentukan kawasan yang paling mungkin bertindak sebagai penerima masukan (input). Peringkat kedua adalah pembinaan model intrahemisfera. Model untuk setiap hemisfera dibina untuk setiap subjek dalam setiap kumpulan umur. Pembinaan model untuk hemisfera kiri dan kanan dilakukan secara berasingan. Dalam kajian ini, untuk BRT, sebanyak 200 model kehubungan efektif intrahemisfera dan 150 interhemisfera dibina bagi masingmasing tugasan dalam senyap dan hingar bagi menguji kewujudan gandingan antara girus temporal superior (STG), girus Heshl (HG) dan girus presentral (PCG) untuk kesemua subjek.

\section{KEPUTUSAN}

Bagi analisis DCM untuk kajian FRT-senyap dan FRT-hingar ini, enam kawasan otak telah dipilih melalui analisis kesan rawak (RFX), kawasan yang dipilih adalah lobus temporal (bilateral STG dan HG) dan bilateral PCG $\left(p_{\text {diperbetulkan }}<0.001\right)$. Pemilihan kawasan bilateral STG dan HG adalah selaras dengan penggunaan stimulus verbal, serta penglibatan STG dan HG ini dalam pemprosesan maklumat auditori. Kawasan STG adalah lebih responsif kepada rangsangan auditori kompleks berbanding HG, yang agak sensitif terhadap tahap nada tulen (Manan et al. 2013b). Kawasan PCG pula memainkan peranan penting dalam pemprosesan persepsi pertuturan.

Kehubungan efektif antara kawasan yang teraktif semasa pemprosesan persepsi pertuturan dengan menggunakan tugasan mengulang secara terus dalam senyap (FRT-senyap) dan dalam hingar latar $5 \mathrm{~dB}$ SNR (FRT-hingar) ini dapat dikaji dengan menggunakan analisis pemodelan dinamik penyebab (DCM). Koordinat kawasan yang dipilih ini adalah kawasan yang berkaitan dengan pemprosesan auditori; STG (BA 22), HG dan pemprosesan persepsi pertuturan. Bagi memilih model optimum antara kesemua model yang dibina, analisis BMS RFX dilakukan ke atas setiap model yang dibina. Nilai kebarangkalian jangkauan bagi model optimum mesti melebihi nilai 0.9. Nilai kebarangkalian jangkauan ini memberi gambaran bahawa model yang dipilih adalah model yang paling tepat dalam menggambarkan kehubungan efektif berbanding model lain.

\section{INPUT AUDITORI}

Jadual 2 menunjukkan nilai kehubungan efektif purata bagi masukan input STG (BA 22) dalam keempat-empat kumpulan umur dalam kedua-dua tugasan. Semua nilai yang dinyatakan tersebut adalah dalam unit $\mathrm{Hz}$.

Bagi FRT-senyap, keempat-empat kumpulan umur memilih model yang menunjukkan bilateral STG (BA 22) adalah pusat masukan isyarat auditori. Bagi FRT-senyap, nilai purata kehubungan efektif menunjukkan lebih 
JADUAL 2. Nilai kehubungan efektif purata bagi masukan input STG (BA 22) bagi keempat-empat kumpulan umur bagi tugasan FRT-senyap dan FRT-hingar

\begin{tabular}{ccccc}
\hline & \multicolumn{2}{c}{ FRT-senyap } & \multicolumn{2}{c}{ FRT-hingar } \\
\cline { 2 - 5 } & \multicolumn{3}{c}{ STG } \\
\cline { 2 - 5 } Kumpulan umur & Kiri & Kanan & Kiri & Kanan \\
\hline $20-29$ & $0.66 \mathrm{~Hz}$ & $0.82 \mathrm{~Hz}$ & $0.71 \mathrm{~Hz}$ & $0.88 \mathrm{~Hz}$ \\
$30-39$ & $0.81 \mathrm{~Hz}$ & $0.93 \mathrm{~Hz}$ & $0.87 \mathrm{~Hz}$ & $0.88 \mathrm{~Hz}$ \\
$40-49$ & $0.88 \mathrm{~Hz}$ & $0.79 \mathrm{~Hz}$ & $0.76 \mathrm{~Hz}$ & $0.76 \mathrm{~Hz}$ \\
$50-65$ & $0.86 \mathrm{~Hz}$ & $0.67 \mathrm{~Hz}$ & $0.78 \mathrm{~Hz}$ & $0.69 \mathrm{~Hz}$ \\
\hline
\end{tabular}

tinggi pada sebelah kanan hemisfera bagi kumpulan 1 dan 2. Manakala, kumpulan 3 dan 4 menunjukkan nilai kehubungan efektif lebih tinggi pada masukan sebelah kiri hemisfera. Bagi FRT-hingar, model optimum yang dipilih untuk keempat-empat kumpulan umur juga menunjukkan masukan input adalah pada bilateral STG (BA 22). Jika dibandingkan, nilai kehubungan efektif antara kiri dan kanan hemisfera, kumpulan 1 dan 2 menunjukkan nilai kehubungan efektif yang lebih tinggi pada sebelah kanan hemisfera. Kumpulan 3 pula menunjukkan perbezaaan yang tidak bererti antara kedua-dua hemisfera. Walau bagaimanapun, keadaan ini berubah apabila usia meningkat, kumpulan 4 menunjukkan nilai kehubungan yang lebih tinggi pada sebelah kiri hemisfera.

\section{KEHUBUNGAN EFEKTIF BAGI FRT-SENYAP DAN FRT-HINGAR}

Rajah 2 menunjukkan model tindak balas neuron yang menunjukkan nilai kehubungan intrinsik purata bagi kehubungan antara enam kawasan otak yang terlibat dalam pemprosesan persepsi pertuturan dengan menggunakan tugasan FRT-senyap. Keputusan DCM menunjukkan semua kumpulan umur memilih model kehubungan intrahemisfera yang sama tetapi berbeza kehubungan interhemisfera. Keputusan DCM juga menunjukkan apabila usia semakin meningkat semakin kompleks perhubungan interhemisfera model yang dipilih. Keputusan nilai intrinsik kehubungan efektif juga menunjukkan perkadaran terus dengan peningkatan umur.

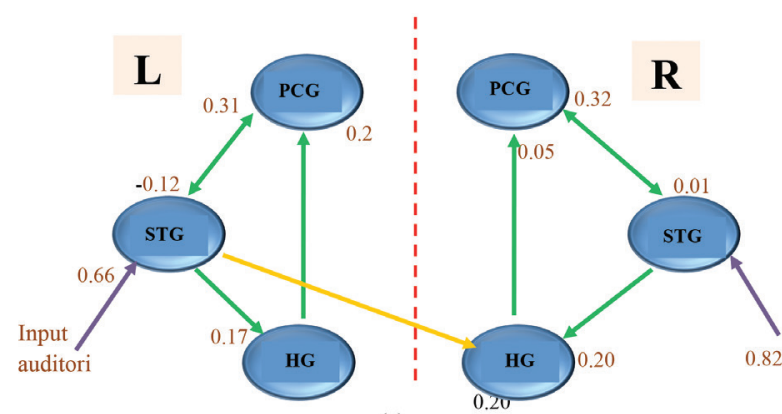

(a)

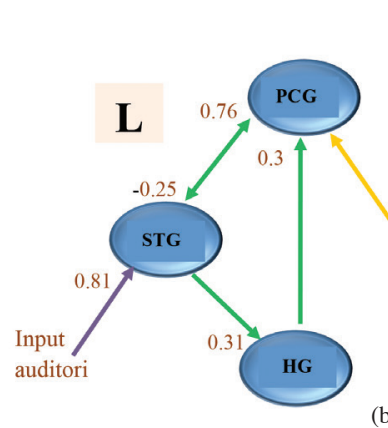

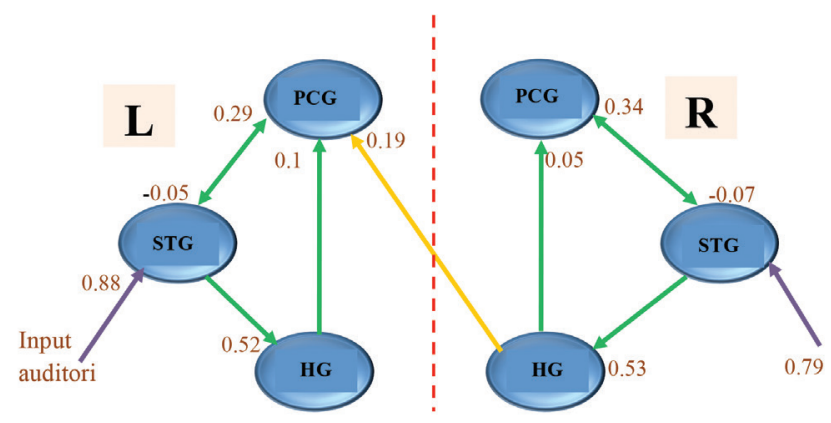

(c)

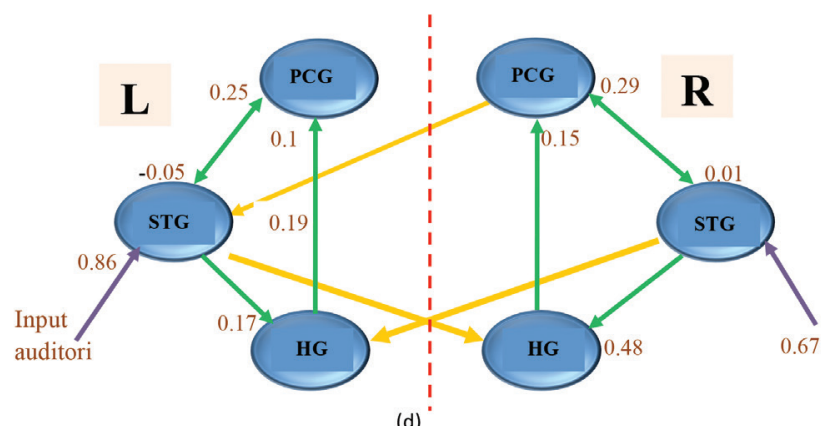

Garisan kuning menunjukkan kehubungan interhemisfera, manakala garisan hijau menunjukkan kehubungan intrahemisfera STG $=$ Girus Temporal Superior, Girus Precentral $=$ PCG, $\mathrm{HG}=$ Girus Heschle, $\mathrm{TH}=$ Talamus, $\mathrm{L}=$ kiri, $\mathrm{R}=$ kanan

RAJAH 2. Model kehubungan efektif yang menunjukkan model optimum dalam menerangkan tindak balas kehubungan yang berlaku di dalam otak bagi (a) kumpulan 1 (20 - 29 tahun), kumpulan 2 (30 - 39 tahun), kumpulan 3 (40 - 49 tahun) dan kumpulan 4 (50 - 65 tahun) bagi tugasan FRT-senyap. Nilai kehubungan efektif purata ditunjukkan (semua nilai yang dipamerkan adalah dalam unit $\mathrm{Hz}$ ) 
Rajah 3 pula menunjukkan nilai kehubungan intrinsik purata bagi tugasan FRT-hingar. Keempat-empat kumpulan umur memilih model optimum yang sama bagi menunjukkan hubungan intrahemisfera tetapi berbeza dalam kehubungan intrinsik interhemisfera. Keputusan nilai kehubungan intrinsik ini juga menunjukkan peningkatan pada nilai kehubungan apabila usia meningkat. Keputusan juga menunjukkan kehubungan efektif semakin kompleks dengan peningkatan usia.

Keputusan perbandingan antara model optimum FRTsenyap dan FRT-hingar menunjukkan: nilai kehubungan efektif adalah lebih tinggi dalam tugasan hingar berbanding dengan tanpa hingar dan kehubungan antara interhemisfera adalah lebih kompleks dalam tugasan dalam hingar.

\section{PERBINCANGAN}

\section{KEHUBUNGAN KEFUNGSIAN MASUKAN INPUT AUDITORI}

Bagi kumpulan 1, FRT-senyap dan FRT-hingar menunjukkan nilai masukan input adalah lebih tinggi pada sebelah kanan hemisfera. Keadaan ini mungkin disebabkan oleh sistem pemprosesan auditori dalam kumpulan 1 berada dalam keadaan masih utuh, jadi bagi melakukan tugasan dalam senyap dan hingar, keperluan kapasiti pemprosesan auditori yang sama diperlukan. Keputusan ini jelas memperlihatkan sistem pemprosesan auditori masih berada dalam keadaan optimum dan hingar tidak memberikan kesan negatif terhadap sistem pemprosesan auditori (Manan et al. 2015). Kumpulan 2 dan 3 pula menunjukkan nilai masukan input yang lebih tinggi pada sebelah kiri hemisfera bagi FRT-senyap dan sebelah kanan hemisfera bagi FRT-hingar. Perbezaaan pada dominasi masukan input auditori ini dicadangkan disebabkan oleh pengaruh hingar. Kebolehan mendengar dan mendiskriminasi juga berkurang disebabkan hingar dan keadaan ini turut dipengaruhi oleh faktor usia. Keadaan ini menyebabkan keperluan pemprosesan yang lebih tinggi dalam melakukan tugasan yang sama berbanding dengan usia muda. Keadaan yang sama turut dilapor oleh pengkaji sebelum ini (Cabeza et al. 2002; Winecoff et al. 2011).

Kumpulan 4 pula menunjukkan nilai masukan input adalah lebih tinggi pada sebelah kiri hemisfera untuk kedua-dua tugasan. Nilai masukan input yang tinggi pada sebelah kiri hemisfera ini adalah bertepatan dengan kajian sebelum ini yang menunjukkan fungsi kognitif pada sebelah kanan hemisfera merosot lebih awal (Cabeza \& Moscovitch 2013; Cabeza \& St Jacques 2010).

Perubahan dominasi hemisfera masukan input ini dicadangkan dipengaruhi oleh banyak faktor. Walau

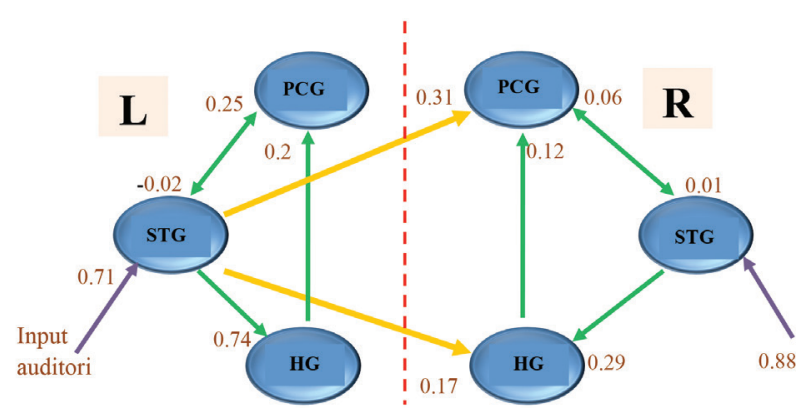

(a)

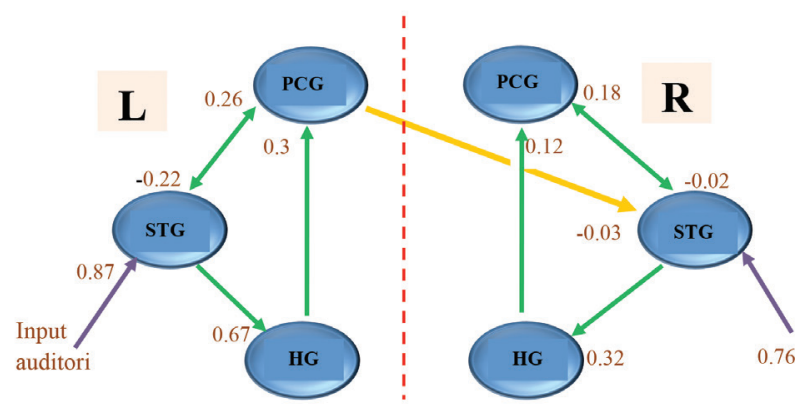

(b)

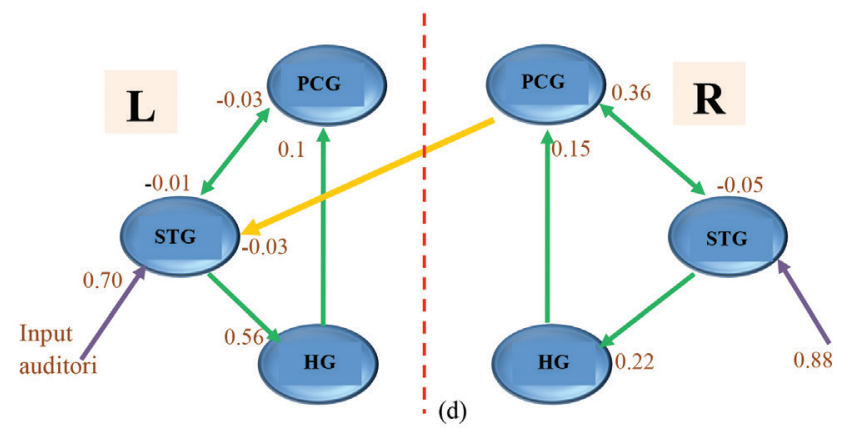

garisan kuning menunjukkan kehubungan interhemisfera, manakala garisan hijau menunjukkan kehubungan intrahemisfera $\mathrm{STG}=$ Girus Temporal Superior, Girus Precentral $=$ PCG, $\mathrm{HG}=$ Girus Heschle, $\mathrm{TH}=$ Talamus, $\mathrm{L}=$ kiri, $\mathrm{R}=$ kanan

RAJAH 3. Model kehubungan efektif yang menunjukkan model optimum dalam menerangkan tindak balas kehubungan yang berlaku di dalam otak bagi (a) kumpulan 1 (20 - 29 tahun), kumpulan 2 (30 - 39 tahun), kumpulan 3 (40 - 49 tahun) dan kumpulan 4 (50 - 65 tahun) bagi tugasan BRT-hingar. Nilai kehubungan efektif purata ditunjukkan (semua nilai yang dipamerkan adalah dalam unit $\mathrm{Hz}$ ) 
bagaimanapun, dalam kajian ini dicadangkan keadaan ini adalah disebabkan oleh faktor penuaan. Apabila usia semakin meningkat, fungsi otak akan mengalami perubahan. Perubahan yang paling jelas pada sistem otak ialah kemerosotan pada jirim-kelabu dan jirimputih (Cabeza et al. 2012, 2003, 1997a). Kajian juga menunjukkan kemerosotan jirim-kelabu dan jirim-putih pada hemisfera kanan adalah lebih cepat berbanding dengan bahagian hemisfera kiri (Cabeza 2013). Ini adalah disebabkan oleh nisbah jirim-kelabu dan jirim-putih adalah lebih banyak di sebelah kiri hemisfera berbanding dengan sebelah kanan hemisfera (Cabeza et al. 1997b). Keadaan ini menyebabkan keperluan kapasiti pemprosesan pada bahagian kiri otak meningkat bagi mengimbangi kemerosotan yang lebih awal pada sebelah kanan hemisfera. Pada masa yang sama keadaan ini juga berlaku disebabkan oleh kemerosotan kognitif yang lain, walaupun stimulus yang sama diberikan tetapi untuk memproses stimulus yang sama kapasiti pemprosesan yang berbeza diperlukan (Cabeza \& Moscovitch 2013). Ini seterusnya meningkatkan nilai kehubungan efektif pada sebelah kiri otak dalam kumpulan berusia. Keadaan yang sama juga berlaku dengan kehadiran hingar latar belakang. Proses mendiskriminasi hingar latar dan rangsangan sasaran menjadi sukar apabila fungsi auditori dan kognitif merosot (Daselaar et al. 2015). Kemerosotan ini adalah dicadangkan juga menjadi faktor kepada perubahan dominasi pada kekuatan kehubungan intrinsik.

\section{KEHUBUNGAN KEFUNGSIAN DALAM TUGASAN FRT}

Keputusan kajian ini menunjukkan manipulasi kognitif dikaitkan dengan perubahan pada kawasan auditori dan kawasan temporal. Keputusan kajian juga menunjukkan keempat-empat kumpulan umur dengan tugasan FRTsenyap dan FRT-hingar memilih model optimum yang menunjukkan corak kehubungan efektif intrahemisfera yang sama tetapi berbeza pada corak kehubungan efektif interhemisfera.

Corak kehubungan model optimum bagi kesemua kumpulan dalam tugasan FRT-senyap dan FRT-hingar menunjukkan bilateral STG memodulasikan kehubungan yang bererti dengan semua kawasan (PCG dan HG). Corak kehubungan ini adalah bertepatan dengan fungsi STG sebagai pusat masukan input dan STG ini juga adalah dicadangkan bertindak sebagai kawasan pengantara fungsi kognitif dalam tugasan persepsi pertuturan ini. Ini jelas dapat dilihat dalam keputusan kajian yang menunjukkan penglibatan kehubungan STG dengan semua kawasan dan cadangan ini adalah konsisten dengan penggunaan stimulus dalam bentuk verbal (Burton \& Small 2006; Small \& Burton 2002) dan pada masa yang sama penglibatan STG dalam pemprosesan maklumat auditori (Hickok et al. 1997). STG menunjukkan kehubungan salingan dengan PCG. Kehubungan salingan antara STG dan PCG ini adalah dicadangkan disebabkan oleh peranan utama yang dimainkan oleh PCG dalam pemprosesan persepsi pertuturan. PCG memainkan peranan penting dalam pengulangan semula maklumat yang sangat penting bagi memastikan input auditori kekal dalam sistem pemprosesan ingatan lisan (Gandour et al. 2003). Corak kehubungan model optimum untuk semua kumpulan umur bagi tugasan FRT-senyap dan FRT-hingar juga menunjukkan corak kehubungan yang selari STG - HG - PCG - STG untuk kedua-dua belah hemisfera. Kajian ini mencadangkan keadaan ini adalah bertepatan dengan pergerakan isyarat neuron dalam memproses maklumat persepsi pertuturan ini. Konsep pemprosesan pertuturan ini melibatkan pendengar memberi tumpuan kepada isyarat auditori dan melaksanakan analisis akustik dengan STG dan HG akan memainkan peranan. Sementara itu, proses menyimpan maklumat akustik dalam ingatan untuk pemprosesan selanjutnya (peranan dimainkan oleh PCG) dan akhir sekali pemetaan fonem kepada makna (Gandour et al. 2002).

\section{KEHUBUNGAN KEFUNGSIAN DALAM FRT-SENYAP}

Corak kehubungan model optimum interhemisfera dalam kumpulan 1 (STGL - HGR) dan kumpulan 2 (PCGL - STGR) dimodulasikan dari kiri ke kanan hemisfera. Manakala corak kehubungan interhemisfera untuk kumpulan 3 (PCGR -STGL) dan kumpulan 4 (PCGR - STGL) pula dimodulasikan daripada kanan ke kiri hemisfera. Perubahan pada modulasi kehubungan intrinsik ini dicadangkan disebabkan oleh faktor penuaan. Kajian sebelum ini ada melaporkan keputusan yang sama, keadaan ini dicadangkan disebabkan oleh kemerosotan hemisfera kanan berlaku lebih awal daripada hemisfera kiri (Dennis et al. 2007; St Jacques et al. 2010). Keputusan ini bertentangan antara kumpulan 1 dan 2 dengan bahagian kiri otak memodulasikan kehubungan interhemisfera. Keputusan kumpulan 1 dan 2 ni menyokong bahawa keadaan ini disebabkan oleh faktor penuaan. Faktor penuaan menyebabkan fungsi kognitif semakin merosot, oleh itu, bagi menyeimbang kemerosotan ini lebih banyak kawasan otak digunakan dalam menghubungkan antara kedua hemisfera (St Jacques et al. 2010).

\section{KEHUBUNGAN KEFUNGSIAN DALAM FRT-HINGAR}

Berbanding dengan FRT-senyap, FRT-hingar menunjukkan corak interaksi kehubungan interhemisfera yang dimodulasikan dari kanan ke kiri hemisfera untuk keempatempat kumpulan umur, kecuali kumpulan 4 menunjukkan hubungan interhemisfera dimodulasikan oleh kedua-dua belah hemisfera otak. Selain faktor usia, faktor hingar juga perlu diberi perhatian dalam tugasan FRT-hingar. Bagi tugasan ini, kajian ini mencadangkan corak interaksi ini adalah disebabkan oleh kehadiran hingar latar yang menyebabkan peningkatan dalam kapasiti pemprosesan maklumat persepsi pertuturan. Hingar ini juga bertindak sebagai gangguan dengan sistem kognitif perlu berada dalam keadaan optimum bagi membolehkan pemprosesan maklumat ini berlaku dengan optimum. Dengan kehadiran hingar, keupayaan penumpuan yang lebih tinggi diperlukan dalam memberi tumpuan kepada stimulus utama atau dalam mendiskriminasi antara pertuturan dan hingar latar. Ini kerana individu berusia sangat terganggu oleh bunyi novel tidak relevan misalnya hingar berbanding 
individu muda (Soderlund et al. 2010; Sohn \& Lee 2000). Keputusan terdahulu menunjukkan bahagian kanan hemisfera merosot lebih awal berbanding kiri hemisfera (Cabeza et al. 2002; Davis et al. 2012; Dolcos et al. 2002). Justeru, bagi membolehkan pemprosesan persepsi pertuturan berlaku pada tahap optimum, bahagian otak yang lain akan menyeimbang kemerosotan ini, iaitu dengan turut sama bekerjasama dalam memproses maklumat persepsi pertuturan. Bagi kes ini bahagian kanan hemisfera turut memodulasikan kehubungan pada kiri hemisfera (Malpetti et al. 2017).

Kumpulan 1 menunjukkan komunikasi interhemisfera dimodulasikan oleh PCGR - STGL. Kami mencadangkan keadaan ini adalah disebabkan kedua kawasan otak tersebut memainkan peranan yang penting dalam tugasan kognitif. STG bertindak sebagai kawasan pengantara antara pemprosesan auditori dan persepsi pertuturan. Manakala PCG pula bertindak sebagai tapak pemprosesan ingatan (dapatan semula) (Toscano et al. 2010). Kumpulan 2 pula menunjukkan model yang sama kompleks dengan kumpulan 1. Model optimum juga menunjukkan interaksi kanan ke kiri dimodulasikan oleh PCGR - PCGL. Kumpulan 3 juga menunjukkan perhubungan interhemisfera dimodulasikan oleh bahagian kanan hemisfera iaitu dari HGR - PCGL. Akhir sekali kumpulan 4 yang menunjukkan perhubungan interhemisfera yang paling kompleks berbanding keempat-empat kumpulan umur dengan model optimum yang dipilih menunjukkan hubungan interhemisfera dimodulasikan oleh kedua-dua belah hemisfera; STGR - HGL dan STGL - HGR. Kekompleksan yang ditunjukkan oleh model optimum kumpulan 4 dicadangkan disebabkan oleh faktor penuaan dan pada masa yang sama disebabkan oleh kehadiran hingar latar. Penuaan disertai dengan kehilangan kebolehan untuk mendiskriminasi hingar dan stimulus utama dan pada masa yang sama kemerosotan pada sistem kognitif juga berlaku (Perkell et al. 2007). Oleh itu bagi mengimbangi kemerosotan pada sistem kognitif dan sistem auditori ini, lebih banyak kapasiti neuron diperlukan untuk melakukan tugasan yang diberi. Dapat disimpulkan disini, bagi melakukan tugasan yang sama dengan hasil yang sama dan bagi menyeimbang kemerosotan pada sistem kognitif dan auditori, kapasiti interaksi neuron interhemisfera yang lebih diperlukan.

\section{KESIMPULAN}

Keputusan DCM dalam kajian yang menggunakan tugasan FRT dalam senyap dan hingar ke atas lima puluh empat orang subjek lelaki Melayu dewasa sihat dan dominan tangan kanan ini menunjukkan keempat-empat kumpulan umur memilih masukan input model DCM yang sama iaitu masukan pada bilateral STG, ini adalah bertepatan dengan stimulus auditori yang digunakan. Kesemua kumpulan umur juga memilih model DCM yang sama bagi menerangkan interaksi intrahemisfera yang berlaku di dalam otak semasa tugasan FRT-senyap dan FRT-hingar. Walau bagaimanapun, keempat-empat kumpulan umur memilih model interaksi interhemisfera yang berbeza dalam menerangkan interaksi neuron semasa tugasan FRT-senyap dan FRT-hingar. Keputusan juga menunjukkan semakin meningkat usia semakin kompleks model interaksi interhemisfera yang dipilih. Ini adalah bertepatan dengan hipotesis yang menunjukkan otak akan merekrut kawasan kontralateral bagi menyeimbangi kemerosotan yang berlaku.

\section{PENGHARGAAN}

Pengarang mengucapkan berbanyak terima kasih kepada En. Sa'don Samian daripada Jabatan Radiologi, Pusat Perubatan Universiti Kebangsaan Malaysia, En. Mohammad Hairol Isa daripada Jabatan Kesihatan Masyarakat Pusat Perubatan Universiti Kebangsaan Malaysia dan Dr. Noorazrul Azmie Yahya daripada Program Pengimejan Diagnostik dan Radioterapi, Universiti Kebangsaan Malaysia. Kajian ini dibiaya oleh Geran Penyelidikan Universiti UKM-GUP-SK 07-020-205.

\section{RUJUKAN}

Abdul Manan, H., Yusoff, A.N. \& Mukari, S.Z.M.S. 2015. Kesan penuaan ke atas kehubungan berkesan otak semasa pemprosesan ingatan bekerja daripada perspektif pemodelan sebab dan akibat dinamik. Sains Malaysiana 44(9): 13391350.

Alain, C., Roye, A. \& Salloum, C. 2014. Effects of age-related hearing loss and background noise on neuromagnetic activity from auditory cortex. Frontiers in Systems Neuroscience 2014: Article ID. 24550790.

Anthony, J.C., LeResche, L., Niaz, U., von Korff, M.R. \& Folstein, M.F. 1982. Limits of the 'mini-mental state' as a screening test for dementia and delirium among hospital patients. Psychological Medicine 12(2): 397-408.

Babkoff, H. \& Fostick, L. 2017. Age-related changes in auditory processing and speech perception: Cross-sectional and longitudinal analyses. European Journal of Ageing 14(3): 269-281.

Brooks, C.J., Anderson, A.J., Roach, N.W., McGraw, P.V. \& McKendrick, A.M. 2015. Age-related changes in auditory and visual interactions in temporal rate perception. Journal of Vision 15(16): 2.

Burton, M.W. \& Small, S.L. 2006. Functional neuroanatomy of segmenting speech and nonspeech. Cortex 42(4): 644-651.

Cabeza, R. 2013. Introduction to the special issue on functional neuroimaging of episodic memory. Neuropsychologia 51(12): 2319-2321.

Cabeza, R., Ciaramelli, E. \& Moscovitch, M. 2012. Cognitive contributions of the ventral parietal cortex: An integrative theoretical account. Trends in Cognitive Sciences 16(6): 338-352.

Cabeza, R.,Locantore, J.K. \& Anderson, N.D. 2003. Lateralization of prefrontal activity during episodic memory retrieval: Evidence for the production-monitoring hypothesis. Journal of Cognitive Neuroscience 15(2): 249-259.

Cabeza, R., Anderson, N.D., Locantore, J.K. \& McIntosh, A.R. 2002. Aging gracefully: Compensatory brain activity in high-performing older adults. Neuroimage 17(3): 1394-1402.

Cabeza, R., Grady, C.L., Nyberg, L., McIntosh, A.R., Tulving, E., Kapur, S., Jennings, J.M., Houle, S. \& Craik, F.I. 1997a. Age-related differences in neural activity during memory 
encoding and retrieval: A positron emission tomography study. Journal of Neuroscience 17(1): 391-400.

Cabeza, R., McIntosh, A.R., Tulving, E., Nyberg, L. \& Grady, C.L. 1997b. Age-related differences in effective neural connectivity during encoding and recall. Neuroreport 8(16): 3479-3483.

Cabeza, R. \& Moscovitch, M. 2013. Memory systems, processing modes, and components: Functional neuroimaging evidence. Perspective on Psychological Science 8(1): 49-55.

Cabeza, R. \& St. Jacques, P. 2007. Functional neuroimaging of autobiographical memory. Trends in Cognitive Science 11(5): 219-227.

Daselaar, S.M., Iyengar, V., Davis, S.W., Eklund, K., Hayes, S.M. \& Cabeza, R.E. 2015. Less wiring, more firing: Lowperforming older adults compensate for impaired white matter with greater neural activity. Cerebral Cortex 25(4): 983-990.

Davis, S.W., Kragel, J.E., Madden, D.J. \& Cabeza, R. 2012. The architecture of cross-hemispheric communication in the aging brain: Linking behavior to functional and structural connectivity. Cerebral Cortex 22(1): 232-242.

Dennis, N.A., Kim, H. \& Cabeza, R. 2007. Effects of aging on true and false memory formation: An fMRI study. Neuropsychologia 45(14): 3157-3166.

Desmond, J.E. \& Chen, S.H.A. 2002. Ethical issues in the clinical application of fMRI: Factors affecting the validity and interpretation of activations. Brain and Cognition 50(3): 482-497.

Desmond, J.E. \& Glover, G.H. 2002. Estimating sample size in functional MRI (fMRI) neuroimaging studies: Statistical power analyses. Journal of Neuroscience Methods 118(2): 115-128.

Dolcos, F., Rice, H.J. \& Cabeza, R. 2002. Hemispheric asymmetry and aging: Right hemisphere decline or asymmetry reduction. Neuroscience \& Biobehavioural Reviews 26(7): 819-825.

Gandour, J., Dzemidzic, M., Wong, D., Lowe, M., Tong, Y., Hsieh, L., Satthamnuwong, N. \& Lurito, J. 2003. Temporal integration of speech prosody is shaped by language experience: an fMRI study. Brain Language 84(3): 318-336.

Gandour,J., Wong, D., Lowe, M., Dzemidzic, M., Satthamnuwong, N., Tong, Y. \& Lurito, J. 2002. Neural circuitry underlying perception of duration depends on language experience. Brain Language 83(2): 268-290.

Habes, M., Janowitz, D., Erus, G., Toledo, J.B., Resnick, S.M., Doshi, J., Van der Auwera, S., Wittfeld, K., Hegenscheid, K., Hosten, N., Biffar, R., Homuth, G., Volzke, H., Grabe, H.J., Hoffman, W. \& Davatzikos, C. 2016. Advanced brain aging: Relationship with epidemiologic and genetic risk factors, and overlap with Alzheimer disease atrophy patterns. Translational Psychiatry 6: e775.

Hall, D.A., Haggard, M.P., Akeroyd, M.A., Palmer, A.R., Summerfield, A.Q., Elliott, M.R., Gurney, E.M. \& Bowtell, R.W. 1999. Sparse temporal sampling in auditory fMRI. Human Brain Mapping 7(3): 213-223.

Hickok, G., Love, T., Swinney, D., Wong, E.C. \& Buxton, R.B. 1997. Functional MR imaging during auditory word perception: A single-trial presentation paradigm. Brain Language 58(1): 197-201.

Li, H.J., Hou, X.H., Liu, H.H., Yue, C.L., Lu, G.M. \& Zuo, X.N 2015. Putting age-related task activation into large-scale brain networks: A meta-analysis of 114 fMRI studies on healthy aging. Neuroscience \& Biobehavioral Reviews 57: 156-174.

Malpetti, M., Ballarini, T., Presotto, L., Garibotto, V., Tettamanti, M. \& Perani, D. 2017. Gender differences in healthy aging and Alzheimer's Dementia: A 18 F-FDG-PET study of brain and cognitive reserve. Human Brain Mapping 38(8): $4212-4227$.

Manan, H.A., Franz, E.A. Yusoff, A.N. \& Mukari, S.Z.M.S. 2015 The effects of aging on the brain activation pattern during a speech perception task: an fMRI study. Aging Clinical and Experimental Research 27(1): 27-36.

Manan, H.A., Franz, E.A., Yusoff, A.N. \& Mukari, S.Z.M.S 2014. Age-related brain activation during forward and backward verbal memory tasks. Neurology, Psychiatry and Brain Research 20(4): 76-86.

Manan, H.A., Franz, E.A., Yusoff, A.N. \& Mukari, S.Z.M.S 2013a. Age-related laterality shifts in auditory and attention networks with normal ageing: Effects on a working memory task. Neurology, Psychiatry and Brain Research 19(4): 180-191.

Manan, H.A., Franz, E.A., Yusoff, A.N. \& Mukari, S.Z.M.S 2013b. The effects of background noise on brain activity using speech stimuli on healthy young adults. Neurology, Psychiatry and Brain Research 19(4): 207-215.

Manan, H.A., Franz, E.A., Yusoff, A.N. \& Mukari, S.Z.M.S 2012. Hippocampal-cerebellar involvement in enhancement of performance in word-based BRT with the presence of background noise: An initial fMRI study. Psychology \& Neuroscience 5(2): 247-256.

Molander, B. \& Backman, L. 1990. Age differences in the effects of background noise on motor and memory performance in a precision sport. Experimental Aging Research 16(1-2): 55-60.

Oldfield, R.C. 1971. The assessment and analysis of handedness: The Edinburgh inventory. Neuropsychologia 9(1): 97-113.

Perkell, J.S., Denny, M., Lane, H., Guenther, F., Matthies, M.L., Tiede, M., Vick, J., Zandipour, M. \& Burton, E. 2007. Effects of masking noise on vowel and sibilant contrasts in normal-hearing speakers and postlingually deafened cochlear implant users. Journal of the Acoustical Society of America 121(1): 505-518.

Richardson, H.E. \& Glass, J.N. 2002. A comparison of scoring protocols on the clock drawing test in relation to ease of use, diagnostic group, and correlations with mini-mental state examination. Journal of the American Geriatrics Society 50(1): 169-173.

Small, S.L.\& Burton, M.W. 2002. Functional magnetic resonance imaging studies of language. Current Neurology and Neuroscience Reports 2(6): 505-510.

St Jacques, P., Dolco, F. \& Cabeza R. 2010. Effects of aging on functional connectivity of the amygdala during negative evaluation: A network analysis of fMRI data. Neurobiology of Aging 31(2): 315-327.

Toscano, J.C., McMurray, B., Dennhardt, J. \& Luck, S.J. 2010. Continuous perception and graded categorization: Electrophysiological evidence for a linear relationship between the acoustic signal and perceptual encoding of speech. Psychological Science 21(10): 1532-1540.

Winecoff, A., KLabar, S., Madden, D.J., Cabeza, R. \& Huettel, S.A. 2011. Cognitive and neural contributors to emotion regulation in aging. Social Cognitive and Affective Neuroscience 6(2): 165-176.

Hanani Abdul Manan*

Department of Radiology

University Kebangsaan Malaysia Medical Centre

Jalan Yaacob Latiff, Bandar Tun Razak 
56000 Cheras, Kuala Lumpur, Wilayah Persekutuan Malaysia

Ahmad Nazlim Yusoff

Diagnostic Imaging \& Radiotherapy Program

School of Diagnostic \& Applied Health Sciences

Faculty of Health Sciences

Universiti Kebangsaan Malaysia

Jalan Raja Muda Abdul Aziz

50300 Kuala Lumpur, Wilayah Persekutuan

Malaysia

Siti Zamratol-Mai Sarah Mukari

Audiology Program

School of Rehabilitation Sciences

Faculty of Health Sciences

Universiti Kebangsaan Malaysia

Jalan Raja Muda Abdul Aziz

50300 Kuala Lumpur, Wilayah Persekutuan

Malaysia
*Pengarang untuk surat-menyurat; email: hanani@ukm.edu.my

Diserahkan: 29 September 2017

Diterima: 23 Mac 2018 